\title{
On the Systematic Bias in Skeletal Sexing
}

\author{
KENNETH M. WEISS \\ Department of Human Genetics, University of Michigan, \\ Ann Arbor, Michigan
}

\begin{abstract}
KEY WORDS Sex ratio · Skeletal sexing · Paleodemography Mortality of adults.
\end{abstract}

\begin{abstract}
Comparison of a large series of sexed adult skeletal populations and a similar series of adult pre-industrial peoples shows that there is a regular and systematic bias in the sexing of adult skeletons. This bias, which is about $12 \%$ in favor of males, is due to the nature of secondary sex characteristics in bone. It should be corrected in skeletal series before demographic analysis is made of them. Application of this knowledge and the same data to problems of age-specific male and female mortality rates is inconclusive, but points to an area for important future investigation. Application to the fossil record confirms some ecological ideas about human evolution.
\end{abstract}

For many purposes, the analysis of a series of excavated skeletons requires that the adult specimens be sexed. On the accuracy of the sexing procedures hinge the results of, for example, analysis of mortality patterns or metric analysis of sexual dimorphism. This paper will look at the sexing procedures as they have been used and will demonstrate that they have resulted in a significant bias which must be considered when sex-specific analysis of skeletal material is attempted.

There are many works which discuss the morphological features of the bones of the skeleton by which sexing can in theory be performed (Hrdlička, '52; Krogman, '62; Bass, '71). The pelvis seems to be the most reliable single bone for this, and it receives the greatest treatment in the literature. Pelves are often not well preserved, however, and in such cases sexing must be performed on the other, less reliable, bones.

Several studies have stressed the increased accuracy in sexing skeletal material which results from the combination of many measurements from a single bone or a series of measurements from different bones; these studies are multivariate in nature (Hanna and Washburn, '53; Pons, '55; Thieme and Schull, '57; Giles, '63). They recognize that as secondary sex characteristics on bone vary from individual to individual and from group to group, one must sex a newfound individual only in comparison to a well analyzed population. These studies derive methods for determining population-specific cutoff points between males and females for the particular array of traits they include.

The multivariate methods which consider populational variation are clearly superior to subjective morphological criteria in that they provide rigorously-defined, objective methods for determining sex and their results seem to be such that fewer specimens are "doubtful" than is the case with the morphological criteria. Unfortunately, however, the more sophisticated methods require better data on which to work; usually, one needs to have the same bones from each individual in the population, and often the measurements to be taken demand a good state of preservation as well. In practice, the data are usually somewhat fragmentary, and the rule seems to be that subjective anatomical criteria are used which differ with each specimen sexed, depending on the bones represented. The vast majority of sexed skeletal populations in the literature have been sexed in this way.

Stewart ('54) and Hrdlička ('52) in fact support subjective methods when performed by experienced professionals. In today's computer parlance they could argue that the trained human brain can 
handle larger arrays of variables than can machines. While this may be the case, there is still good reason sto suspect the results of the sexing which has been done in this way. The reason for this suspicion is the general nature of sex characteristics on bone, which produces an irresistable temptation in many cases to call doubtful specimens male. A great many of these characteristics are of what could be called a "larger-smaller" nature: the larger, or more marked trait is called male. Examples of this are muscle markings on the skull, size of the skull, femoral head size, rugosity of bone, and so forth. While there are many other traits in which presence indicates a female (for example, the pre-auricular sulcus on the pelvis), it seems that the "larger-smaller" traits are often, if not most often, the ones used. In particular, the sexing of specimens by characteristics of the skull is widespread, and many sex reflections in the skull are of the larger-smaller type. This being the case, when a specimen is found in which the traits are of intermediate size, rugosity, or development there seems to be a tendency to call it a male. Thus, a skull with a moderately marked temporal line is likely to be called male: it would be the absence of a marked temporal line which would indicate a female.

There are other reasons to suspect that too many skeletons might be called male. One is expressed by E. A. Hooton, who believed that typological characteristics of various "racial" groups were best found on the males (Hooton, '30), a reflection of the general tradition of basing comparisons on males; with small samples of material, it would be quite tempting to put all doubtful specimens into the male category (S. L. Washburn, personal communication).

Skeletal series themselves might be biased. This could occur as the result of differential burial customs, unrepresentative sites, or poorer preservation of female material. In some cases, other information might lead us to suspect that the site was an unusual one (for example, a monastery graveyard); some of these problems have been discussed by Brothwell (71). Differential preservation does not seem to be the answer, for were this the case one would expect female remains in general to be more deteriorated than males; in the author's experience this is not so: the clearly-female skulls seem as well preserved as the clearly-males. Vallois ('60) argues that even fossil hominid infants preserve as well as adults; if it is true that, historically, anthropometrists sought well-preserved males for comparative studies, still one suspects that even complete series would show an excess of males, because of the nature of the sexing criteria themselves.

\section{Testing for bias}

To determine if the suspected excess of males in fact occurs, a compilation has been made of some 43 populations of adult skeletons from various tíme periods, cultures, and geographic areas. Table 1 shows these data; for each population the total number of adults is listed as well as the percent which were called male and a source reference.

Of the 43 populations shown, 33 had more males than females and only ten had an excess of females. This is significantly different from what would be expected assuming random sampling from populations with male-female equality $(Z>3.0$; $P<0.01)$. The range in percent-male is 39 to 80 . This clearly indicates the bias suspected. There are other ways of looking at the results which also show the degree and significance of the bias.

Weighting the populations equally even though they consist of different numbers of skeletons, one can compute the simple average of the populations' percent males. This is 56.8 , and is significantly different from 50 for 43 populations $(t=3.7$; $\mathrm{P}<0.001)$. Alternatively, if we weight the population by the number of specimens, we merely sum all of the data together. There were 12,064 specimens with an overall percent male of 54.4, which is significantly different from 50 to many decimal places. No matter how we partition the data, the excess of males is systematic, obvious, and statistically significant when compared to a hypothetical expectation of $50 \%$ male.

However, it has not been proved that the problem is in the sexing, for it is possible that $50 \%$ males is not to be expected. In order to establish some control on the sex ratio to be expected, data from 31 
TABLE 1

Adult sex ratios from sheletal populations

\begin{tabular}{|c|c|c|c|}
\hline Population & $\begin{array}{l}\text { Number of } \\
\text { specimens }\end{array}$ & $\begin{array}{l}\text { Percent } \\
\text { male }\end{array}$ & Reference \\
\hline \multicolumn{4}{|l|}{ Amerindians } \\
\hline Pecos Pueblo & 614 & 60 & Hooton. '30 \\
\hline Texas Aboriginals & 507 & 53 & Goldstein, '53 \\
\hline Eva & 69 & 54 & Lewis and Lewis, '61 \\
\hline Californians & 206 & 48 & Brabender, ' 65 \\
\hline Occaneechi & 84 & 57 & Hoyme and Bass, '62 \\
\hline Modoc & 27 & 48 & Neumann, '67 \\
\hline Hiwassee Island & 133 & 61 & Hoyme and Bass, ' 62 \\
\hline Indian Knoll & 511 & 55 & Johnston and Snow, '61 \\
\hline Knight & 98 & 53 & Wilkinson, '71 \\
\hline Norton Mound & 15 & 80 & Wilkinson,' 71 \\
\hline Peruvians & 242 & 57 & MacCurdy, '23 \\
\hline East Greenlanders & 51 & 61 & Pedersen, 49 \\
\hline Eskimos & 224 & 58 & Hanna and Washburn, '53 \\
\hline \multicolumn{4}{|l|}{ Africans } \\
\hline "Negroes" & 187 & 58 & Todd, 27 \\
\hline Northwest Mesolithics & 42 & 62 & Briggs, '55 \\
\hline Taforalt & 86 & 55 & Angel, '69 \\
\hline Nubians & 36 & 53 & Anderson, ' 68 \\
\hline Nubians & 151 & 70 & Smith and Jones, '08 \\
\hline Protohistoric Saharans & 44 & 46 & Chamla, '68 \\
\hline Neolithic Saharans & 41 & 71 & Chamla, '68 \\
\hline Egyptian mummies & 110 & 57 & Pearson, '02 \\
\hline \multicolumn{4}{|l|}{ Japan } \\
\hline Jomon period & 235 & 57 & Kobayashi, '67 \\
\hline Edo period & 166 & 70 & Kobayashi, '67 \\
\hline \multicolumn{4}{|l|}{ Europeans } \\
\hline France Eneolithic & 242 & 46 & Riquet, '53 \\
\hline Westerhus Sweden & 154 & 46 & Gejvall, '60 \\
\hline English medieval & 59 & 85 & Dingwall, ' 31 \\
\hline Yugoslavia & 189 & 55 & Ivaniček, '51 \\
\hline Hungary - Avar period & 31 & 68 & Wenger, '68 \\
\hline Hungary - Xth Century & 600 & 52 & Acsadi and Nemeskeri, '57 \\
\hline Hungary - Xth Century & 47 & 49 & Ery, '70 \\
\hline Hungary - XIIIth Century & 34 & 56 & Ery, 68 \\
\hline Other Hungarians & 639 & 57 & Ery, 68 \\
\hline Rome & 4632 & 53 & MacDonell, '13 \\
\hline Austria Bronze Age & 228 & 53 & Vallois, ' 37 \\
\hline Turkey Copper Age & 159 & 63 & Senyürek, '51 \\
\hline Nea Nikomedeia & 44 & 48 & Angel, '69 \\
\hline Szekesfehervar & 103 & 46 & Angel, '69 \\
\hline Catal Huyuk & 216 & 39 & Angel, 69 \\
\hline Karatas & 230 & 43 & Angel, ' 69 \\
\hline Lerna & 105 & 52 & Angel, '69 \\
\hline Athens Classic & 79 & 57 & Angel, '69 \\
\hline Continental Greece & 362 & 58 & Angel, ' 47 \\
\hline Tasmanians & 32 & 62 & Todd, 27 \\
\hline
\end{tabular}

Total number of populations: 43 . Number at least $50 \%$ male: 33 . Average of population sex ratios: 0.568 male. Total number of skeletons: 12,064 . Overall percent male: 54.4 .

populations of pre-industrial peoples have been compiled in table 2 . Here, an actual census of the living was taken. These populations represent, as well as can be done, the kinds of living conditions which we would have expected for our skeletal populations.
Of the 31 populations listed, only 13 have more males. The unweighted average sex ratio is 48.8 percent male, and weighting by aggregating all individuals shows almost exactly half of the 39,843 people (adults) to be male. It seems reasonable to argue from this that, in the 
TABLE

Adult sex ratios from live pre-industrial populations

\begin{tabular}{|c|c|c|c|}
\hline Population & $\begin{array}{l}\text { Number of } \\
\text { adults }\end{array}$ & $\begin{array}{l}\text { Percent } \\
\text { male }\end{array}$ & Reference \\
\hline \multicolumn{4}{|l|}{ Australians } \\
\hline North Territories & 10806 & 51 & Jones, '63 \\
\hline Pitjandjara & 438 & 50 & Yengoyan,'71 \\
\hline Groote Eylandt & 145 & 55 & Rose, '60 \\
\hline North Queensland & 280 & 49 & Sharp, '40 \\
\hline Central Australia & 1193 & 47 & Meggitt, '68 \\
\hline \multicolumn{4}{|l|}{ Eskimos } \\
\hline East Greenland & 312 & 45 & Mikkelsen and Sveistrup, '44 \\
\hline Greenland & 321 & 45 & Hansen, '11 \\
\hline Greenland & 456 & 45 & Pedersen, '49 \\
\hline Baker Lake & 218 & 50 & Vallee, '67 \\
\hline Angmagssalik & 475 & 48 & Skeller, '54 \\
\hline Labrador & 194 & 49 & Stewart, '39 \\
\hline \multicolumn{4}{|l|}{ Other Amerindians } \\
\hline Nootka & 213 & 55 & Colson, '53 \\
\hline San Luis Obispo & 471 & 44 & Cook, 40 \\
\hline Cayapo Brazil & 366 & 47 & Salzano,'71 \\
\hline Caingang & 1854 & 51 & Salzano, '64 \\
\hline Guarani & 64 & 41 & Salzano, '64 \\
\hline Xavante & 380 & 49 & Neel and Chagnon, '68 \\
\hline Yanomama & 272 & 51 & Neel and Chagnon, '68 \\
\hline Siriono & 91 & 46 & Holmberg, 69 \\
\hline Hutterites 1880 & 230 & 49 & Eaton and Mayer, '53 \\
\hline Birhor (India) & 64 & 55 & Williams, ' 65 \\
\hline Abor (India) & 421 & 52 & Sarkar, '60 \\
\hline Andaman Islands & 196 & 60 & Sarkar, '60 \\
\hline Pygmies & 411 & 49 & Turnbull, '65 \\
\hline Bushmen & 289 & 45 & Lee, '69 \\
\hline Bushmen & 105 & 33 & Lebzelter, '34 \\
\hline Cocos Keeling & 887 & 53 & Smith, ’60 \\
\hline Tiwi & 491 & 47 & Jones, '63 \\
\hline Tikopia & 736 & 50 & Borrie et al., '57 \\
\hline Tsembaga & 127 & 54 & Rappaport, '68 \\
\hline "Kuru-free" New Guinea & 17337 & 49 & Gadjusek et al., '61 \\
\hline
\end{tabular}

Total number of populations: 31 . Number at least $50 \%$ male: 13 . Average of population sex ratios: 0.488 male. Total number of individuals: 39,843 . Overall percent male: 49.6 .

main and in the absence of clear cultural information indicating otherwise, one should expect about an equal number of adult males and females.

This sample of known peoples highlights the significance of the excess of males in the worldwide skeletal sample, and indicates the seriousness of the problem of sexing inaccuracy for either demographic or sexual-dimorphism investigations. For example, if we know that the sex ratio at birth is about $53 \%$ male (Cavalli-Sforza and Bodmer, '71; Van den Berghe, '70; Stern, '60), the adult sex ratio says much about age-specific mortality patterns, especially those for children. We must have confidence that the sex ratio observed among adults is accurate. A $56.8 \%$ male sex ratio for adults implies that there is higher juvenile mortality among females; if that sex ratio is accurate, it would indicate a population very much different from those in our ordinary experience in which male children suffer higher mortality rates than females. Accepting a biased sexing would result in a misunderstanding of the population under study.

Other studies show similar biases toward male skeletons. Brothwell (71) analyzes 27 populations of skeletons and concludes that the data show "encouraging" nearness to female-male equality. His data, however, show 18 of the 27 populations to have more males than females, and a visual fit to his chart (p. 120) yields an unweighted average figure of about $54 \%$ male per population. 
A complex sexing analysis was performed on the material from Jebel Moya by Mukherjee, Rao and Trevor ('55) who determine sex in three ways: original field assessment, laboratory anatomical study, and discriminant function. For most of their data the methods differed widely in the sex attributions they produced, and differences between different scholars working at the site and even between digging seasons were significant. However, the material judged most reliable consisted of at least $54 \%$ males and perhaps more depending on the method used.

Another detailed populational study shows an excess of adult males among the specimens used. This is Hanna and Washburn's ('53) analysis of Eskimo pelves. Their material seems to be $58 \%$ male, while most living Eskimo populations counted show more adult females than males (table 2; Hansen, '11; Skeller, '54). Here, as in the Jebel Moya material, even sophisticated sexing resulted in about the same excess of males which was just observed in the data in table 1 . It cannot simply be assumed that the sexing procedures are in error here also, for in these works special care was taken to be as accurate as possible. There may be slight errors favoring males, as in the sexing of the few intermediate specimens, but one is probably safer in assuming that the data were more male than female. This highlights the fact that it is difficult to determine the source of a given observed sex ratio.

The persistence of the sexing bias is found in a wide range of data. As a general figure, between 10 and $15 \%$ or an average of about $12 \%$ too many males seems a reasonable estimate of the crude error rate in the sexing of adult material, for whatever reason. About $56 \%$ of a population will, on average, be called male when only $50 \%$ ought to. This of course is a statistical fact applying to the net results of many independent studies. It may be due to the general nature of the sex criteria themselves, but the problem is raised as to what to do in order to compensate for this bias now that it is known. Certainly, it would not be reasonable to apply a $12 \%$ correction to all series, for this would assume more than has been shown; we have demonstrated an average error only. For some populations, such as Jebel Moya or the Eskimos, one should be guided by the strength of the evidence indicating the reliability of the data sample or of the sexing procedures. When confidence can be placed in the sexing, the problem is narrowed down to a question of sampling error or the possibility that the particular population actually had the observed sex ratio.

There is no simple way to decide which studies are reliably sexed and which are not. It might be best to avoid using sex information whenever possible. When a site yields no information which can aid morphological evidence in determining an expected sex ratio, it would be a candidate for the application of a correction factor. This would be especially true in the case of many studies in the literature in which populational sexing methods were not used.

\section{Age-specific tests}

For more detailed demographic analysis, the application of a single correction for material at all ages might mask information which could be useful. In particular, there might be differing biases for specimens of differing ages, and one would want to apply an age-specific correction. This is important in that much of interest to demographers lies in age-specific mortality rates by sex.

It is known that among most modern populations males experience higher adult mortality and morbidity rates than females at nearly all ages. The data on this are extensive, but material in Stern ('60) and the life tables in Keyfitz and Flieger (68) will suffice to support these facts. The fact that males are born in greater numbers than females has itself been explained as the result of selection in populations whose males are less hardy than in females, which is an idea going back at least to R. A. Fisher (Crow and Kimura, '70).

In the face of the above, it is surprising that Vallois ('37), Senyürek ('51), and Angel ('69) among many others argue that before very recent times adult females died at an earlier age than did males. The data they use support this idea, in showing the percent-males in- 
TABLE 3

Age-specific sex ratios for live pre-industrial populations

\begin{tabular}{|c|c|c|c|c|}
\hline \multirow{2}{*}{ Population } & \multicolumn{2}{|c|}{ Age $15-30$ (approx.) } & \multicolumn{2}{|c|}{ Over age 30 (approx.) } \\
\hline & Number & $\%$ Male & Number & $\%$ Male \\
\hline \multicolumn{5}{|l|}{ Australians } \\
\hline North Territories & 4078 & 51 & 6728 & 52 \\
\hline Pitjandjara & 178 & 45 & 260 & 53 \\
\hline Groote Eylandt & 74 & 44 & 71 & 65 \\
\hline North Queensland & 86 & 57 & 194 & 45 \\
\hline \multicolumn{5}{|l|}{ Eskimos } \\
\hline East Greenland & 146 & 46 & 166 & 45 \\
\hline Greenland & 340 & 45 & 116 & 45 \\
\hline Baker Lake & 106 & 50 & 112 & 49 \\
\hline Angmagssalik & 293 & 50 & 182 & 44 \\
\hline Labrador & 69 & 54 & 125 & 46 \\
\hline \multicolumn{5}{|l|}{ Other Amerindians } \\
\hline Nootka & 67 & 43 & 146 & 60 \\
\hline San Luis Obispo & 237 & 49 & 234 & 40 \\
\hline Caingang & 1069 & 49 & 785 & 53 \\
\hline Guarani & 38 & 42 & 26 & 38 \\
\hline Xavante & 257 & 51 & 123 & 47 \\
\hline Yanomama & 185 & 51 & 87 & 51 \\
\hline Hutterites 1880 & 112 & 47 & 118 & 50 \\
\hline Birhor (India) & 33 & 58 & 31 & 52 \\
\hline Cocos Keeling & 712 & 53 & 175 & 53 \\
\hline Tiwi & 173 & 47 & 318 & 46 \\
\hline Tikopia & 354 & 52 & 382 & 49 \\
\hline Tsembaga & 55 & 60 & 72 & 49 \\
\hline "Kuru-free" New Guinea & 13251 & 50 & 4086 & 48 \\
\hline
\end{tabular}

Number of populations: 22 .

Age 15-30: Number of individuals: 21,913. Percent of individuals male: 50.1 . Average population sex ratio: 0.497 male. Populations at least $50 \%$ male: 12.

Ages over 30: Number of individuals: 14,537. Percent of individuals male: 50.2. Average population sex ratio: 0.491 male. Populations at least 50 \% male: 9.

creasing with age among adult skeletons. This is directly contrary to modern experience, and another glance at the data used here may aid in determining if there has in fact been a recent and fundamental change in adult human mortality patterns.

Choosing roughly 30 years as the breaking point between young and "old" adults, since the data are more likely to be broken down there, it is possible to examine ageclass changes in sex-specific mortality. Table 3 lists the results from the analysis of 22 living populations. If the notion that pre-industrial societies experienced higher female mortality is to be true, then the data must show the percent males in the over-30 group to be greater than the percent males in the under-30 group. That is, whatever the sex ratio for adults under 30 , if the females die faster there must be relatively more males left in the ages over 30 . If childbirth mortality is the primary cause for the higher female mortality, then most of its effects will be shown across age 30 , since most reproduction occurs before that age (see Barclay, '58).

Table 3 shows that both the weighted and unweighted average sex ratios from ages $15-30$ are almost exactly $50 \%$ male. Twelve of 22 populations show at least $50 \%$. For adults over age 30 , the unweighted average is $49.1 \%$ male, and the weighted (total) is $50.2 \%$. Here nine of 22 populations have at least $50 \%$ males. If anything, the evidence shows the reverse of an excess female mortality; in fact, the sex ratio has declined in 13 and held steady in three of the 22 populations.

This has two consequences: first, there seems to be little difference between the sex ratios for younger and older adults, 
TABLE 4

Age-specific sex ratios for skeletal populations

\begin{tabular}{|c|c|c|c|c|}
\hline \multirow{2}{*}{ Population } & \multicolumn{2}{|c|}{ Age 15-30 (approx.) } & \multicolumn{2}{|c|}{ Over age 30 (approx.) } \\
\hline & Number & $\%$ Male & Number & $\%$ Male \\
\hline \multicolumn{5}{|l|}{ Amerindians } \\
\hline Eva & 22 & 77 & 47 & 42 \\
\hline Indian Knoll & 261 & 50 & 250 & 61 \\
\hline East Greenland Eskimos & 32 & 53 & 19 & 74 \\
\hline \multicolumn{5}{|l|}{ Africans } \\
\hline "Negroes" & 106 & 55 & 81 & 62 \\
\hline Protohistoric Saharans & 20 & 50 & 17 & 47 \\
\hline Canary Islands (Schwidetzky, '58) & 564 & 66 & 1090 & 68 \\
\hline \multicolumn{5}{|l|}{ Japan } \\
\hline Jomon period & 119 & 55 & 116 & 59 \\
\hline Edo period & 46 & 63 & 120 & 72 \\
\hline \multicolumn{5}{|l|}{ Europeans } \\
\hline France Eneolithic & 100 & 45 & 142 & 47 \\
\hline Westerhus Sweden & 84 & 48 & 70 & 44 \\
\hline Yugoslavia & 74 & 40 & 115 & 63 \\
\hline Hungary - Xth Century & 141 & 45 & 459 & 54 \\
\hline Other Hungarians & 246 & 54 & 393 & 60 \\
\hline Lower Austria (Vallois, '37) & 142 & 40 & 86 & 73 \\
\hline Turkey Copper Age & 66 & 52 & 93 & 71 \\
\hline Romans & 2664 & 48 & 1968 & 59 \\
\hline
\end{tabular}

Number of populations: 16 .

Age 15-30: Number of individuals: 4,687. Percent of individuals male: 50.8. Average population sex ratio: 0.526 male. Populations at least $50 \%$ male: 10 .

Ages over 30: Number of individuals: 5,066. Percent of individuals male: 60.9. Average population sex ratio: 0.597 male. Populations at least $50 \%$ male: 12.

and second, the trend does not seem to favor males at later ages. This can be compared with the 16 available skeletal populations which could be broken down at the required ages. Table 4 lists these data. For the younger adults, the unweighted average is $52.6 \%$ male and the weighted $50.8 \%$, with 10 of the 16 populations having at least $50 \%$ males. The older age group has sex ratios of 59.7 (unweighted) and 60.9 (weighted). All but four of the populations show males in excess, and there does seem to be a trend towards increased sex ratio with age.

Thus the skeletal data do support the relative advantage of males at later ages, but clearly show also the general bias in favor of males. If there is a difference in bias at various ages, there would seem to be about $20 \%$ too great a probability that an older skeleton is called male. If true, this could be due either to a tendency to call a bone which shows signs of age male, or to sex-specific differences in age and sex criteria themselves (e.g., different rates of cranial suture closure for each sex).
Even applying a blanket $12 \%$ correction factor to all of the skeletal data, there is still an increase in percent males with age, from $47 \%$ under age 30 to $52 \%$ over 30 . This would tend to reinforce the arguments of demographers that earlier cultures experienced higher female mortality rates. Unfortunately, the data from living populations cannot verify this.

There may well be reasons for the failure of living primitives to support a theory observed in skeletal populations. Censused primitive populations may not be representative of all pre-industrial cultures, and in fact may be censused in some way because they are not representative. Contemporary pre-industrial peoples may also have been disrupted enough demographically that the earlier pattern has been changed; one such cause could be a reduced fecundity after contact which might lower childbirth risks enough to change basic male-female mortality differences (on the reduced fertility after contact, see Carr-Saunders, '22). Russell ('58) has noted historical evidence for the high maternal mortality toll which might explain 
earlier patterns. In general, it is not necessarily safe to assume that the living groups reported here are valid controls.

It is necessary to conclude that due to small samples and questionable reliability of control data the age-specific mortality for males and females in pre-industrial societies cannot be determined. Whether there has been a significant and quite recent change in basic patterns cannot be told, but the data presented here do suggest the importance of investigating this phenomenon among the few remaining primitive groups, for important genetic, medical, epidemiological, and economic consequences might depend on our correct understanding of the root causes of human mortality.

\section{A note on fossil man}

It is interesting to take a speculative look at the sex ratio among specimens of fossil hominids. For convenience they are divided into four stages: australopithecine, Homo erectus, Neanderthal, and "early modern." It cannot be claimed that biological populations are represented by the fossils, but since single, isolated specimens have regularly been sexed, one can examine the pooled results of the sexing procedures.

Australopithecines are generally grouped into robust and gracile forms, each commonly considered to represent a separate taxon. Recently Brace (72) and others have questioned this taxonomy, and have argued that there is only one taxon of early Pleistocene hominid whose variability is largely a function of sexual dimorphism. Sex attributions in the literature are exclusively made according to the former taxonomy, although for most of the more complete specimens the sexing criteria would probably result in the same attribution within the latter taxonomy as well (sexing is based on robustness, cresting of skull, overall size and so on). As sexed in original reports, $48 \%$ of sexed adult australopithecines have been called male.

For $H$, erectus and Neanderthals, sex attributions are taken from Coon ('62) and Day ('65). The reported adult sex ratios are $55 \%$ male for $H$. erectus and $62.5 \%$ male for Neanderthals. For sev- eral series of Mesolithic, Upper Paleolithic and other groups generally called "early modern" men which have been reported by Vallois (61) and listed in the Appendix of Coon ('62), the sex ratio is $56.3 \%$ male.

The fossil sex ratios have been developed in detail by Weiss (71) where it was shown that there is a statistically significant excess of males overall. The fact that the modern series has a sex ratio very similar to that observed in table 1 leads to the suspicion that a similar sexing bias may be operating here. The fossil sex ratios have therefore been corrected by a $12 \%$ factor, which results in ratios of: australopithecines $43 \%, H$. erectus $49 \%$, Neanderthals $56 \%$, and "early modern" $50 \%$. The use of a $12 \%$ factor is of course tenuous, especially since sexing criteria must be different for fossils than they are for modern man; however, it is no more tenuous than are the guesses as to sex cutoff points for the fossil specimens, and it serves to discount the number of males enough that the resultant sex ratio is statistically not different from an expected $50 \%$ overall.

One can speculate on these results and the meaning they could have in interpreting the population structure of early human populations: In groups of subhuman primates living in East and South African savannahs, there are nearly always more adult females than males. Baboons range from $27-48 \%$ male (Aldrich-Blake et al., '71; Kummer, '68), and even including the subadult males will not raise the sex ratio above $50 \%$. For geladas (Crook and Aldrich-Blake, '68) and for the patas monkey (Hall, '68; Struhsaker and Gartlan, '70) conditions are similar. This is a general condition for most primates (Schultz, '61), although it has not been fully explained.

If savannah primate populations have more adult females than males, and if the australopithecine sex ratio is at all reliable, this would suggest that perhaps savannah-primate group structure applies to them. This would fit the baboon analogy which ecological data from the fossil sites has suggested to many people.

In regard to the later fossil series, all but the Neanderthals are indistinguishable from $50 \%$ male. Brace ('64) dis- 
cusses at length the historical, psychological, and typological reasons why one might expect the Neanderthals to exhibit a great excess of males even after an average bias factor has been applied. If the Neanderthal excess of males is due at least in part to non-ecological reasons, then the fossil sex ratios suggest that by the time Homo erectus had evolved, his population structure closely resembled that of modern hunter-gatherers. Since the archeological evidence has suggested this to others for other reasons, the results from adult sex ratio analysis, while clearly speculative, are a pleasing corroboration of theory concerning the evolution of our ancestral populations in the Pleistocene. This has been done by only the most general use of the fossil sex ratios.

\section{CONCLUSIONS}

Most papers analyzing skeletal demography accept the sexing of the specimens they use and attempt to explain the observed sex ratios in demographic or cultural terms, rather than first questioning the accuracy of the sexing procedures themselves. This questioning was done here, and a systematic, statistically significant bias was found.

It is possible to avoid inaccurate sexing in many cases once one is aware of the bias in the sexing procedures as they have generally been employed. There are a great many large skeletal series which can, and should, be sexed by populational methods. When a new site is excavated, the material should be sexed by comparison with such a well-analyzed series of people closely related to the new site; in most cases today these series exist if they would only be analyzed. The same sex cutoff points could be used on the new site, and this procedure would result in more satisfactory demography for the new data.

For sites which are reported in the literature and whose sexing procedures are unknown or known to be poor, one is safest in assuming that adult males and females should probably be about equal in number. Fluctuations from this would be expected through sampling error, but any deviations above this stochastic level must be explained in some adequate way before the sexing can be used with confidence. Only in a case in which there is simply no information should a blanket correction factor be used; in such cases it would seem that the application of a correction would at least increase the likelihood that the corrected sex ratios were accurate.

\section{ACKNOWLEDGMENTS}

I thank Dr. C. L. Brace and Dr. M. H. Wolpoff for their helpful criticism of the manuscript.

\section{LITERATURE CITED}

Acsadi, G., and J. Nemeskeri 1957 Palaodemographische Probleme am Beispiel des Fruhmit telalterlichen Gräberfeldes von Halimba-Cseres Kom. Veszprém/Ungarn. Homo, 8: 133-147.

Aldrich-Blake, F. P. G., T. K. Bunn, N. I. M. Dunbar and P. M. Headley 1971 Observations on baboons, Papio anubis, in an arid region in Ethiopia. Folia Primat, 15:1-35.

Anderson, J. E. 1968 Late Paleolithic skeletal remains from Nubia. In: The Prehistory of Nubia, Vol. II. F. Wendorf, ed. Southern Methodist University Press, Dallas, pp. 996-1040.

Angel, J. L. 1947 The length of life in ancient Greece. J. of Geront., 2: 18-24.

1969 The bases of paleodemography. Am. J. Phys. Anthrop., 30: 427-438.

Barclay, G. W. 1958 Techniques of Population Analysis. John Wiley, New York.

Bass, W. M. 1971 Human Osteology: A Laboratory and Field Manual of the Human Skeleton. Missouri Archaeological Society, Columbia.

Blakely, R. L. 1971 Comparison of the mortality profiles of Archaic, Middle Woodland, and Middle Mississippian skeletal populations. Am. J. Phys. Anthrop., 34: 43-54.

Borrie, W. D., R. Firth and J. Spillius 1957 The population of Tikopia, 1929 and 1952. Pop. Studies, X: 229-252.

Brabender, I. 1965 Beitrag zur paläobiologischen Rekonstruktion prähistorischer kalifornischer Populationen. Homo, 16: 200-229.

Brace, C. L. 1964 The fate of the "Classic" Neanderthals. Curr. Anthrop., 5: 3-19.

- 1972 Sexual dimorphism in human evolution. Yearbook of Physical Anthropology.

Briggs, L. C. 1955 The Stone Age races of Northwest Africa. Bulletin, American School of Prehistoric Research, 18.

Brothwell, D. R. 1971 Palaeodemography. In: Biological Aspects of Demography. W. Brass, ed. Taylor and Francis, London, pp. 111-130.

Cavalli-Sforza, L. L., and W. F. Bodmer 1971 The Genetics of Human Populations. W. H. Freeman, San Francisco.

Carr-Saunders, A. M. 1922 The Population Problem: A Study in Human Evolution. Clarendon Press, Oxford. 
Chamla, M-C. 1968 Les Populations Anciennes du Sahara et des Régions Limitrophes. Mémoires, Centre de Recherches Anthropologiques Prehistoriques et Ethnographiques, IX. Arts et Métiers Graphiques, Paris.

Colson, E. 1953 The Makah Indians. University of Minnesota Press, Minneapolis.

Cook, S. F. 1940 Population Trends Among the California Mission Indians. Ibero-Americana, 17.

Coon, C. S. 1962 The Origin of Races. A. A. Knopf, New York.

Crook, J. H., and P. Aldrich-Blake 1968 Ecological and behavioral contrasts between sympatric ground dwelling primates in Ethiopia. Folia Primat., 8: 192-227.

Crow, J. F., and M. Kimura 1970 An Introduction to Population Genetics Theory. Harper and Row, New York.

Day, M. H. 1965 Guide to Fossil Man. Meridian, Cleveland.

Dingwall, D. 1931 A barrow at Dunstable, Bedfordshire: the skeletal material. J. Archaeology, $88: 210-217$.

Eaton, J. W., and A. J. Mayer 1953 The social biology of very high fertility among the Hutterites: the demography of a unique population. Human Biol., 25: 206-264.

Ery, K. K. 1968 Anthropological studies on a Late Roman population at Majs, Hungary. Anthrop. Hungarica, $8: 31-58$.

1970 Anthropological studies on a tenth century population at Kal, Hungary. Anthrop. Hungarica, 9: 9-62.

Gajdusek, D. C., V. Zigas and J. Baker 1961 Studies on Kuru III: patterns of Kuru incidence - demographic and geographic epidemiological analysis. J. Trop. Med. and Hygiene, 10: 599627.

Gejvall, N-G. 1960 Westerhus: medieval population and church in the light of skeletal remains. University of Lund, Lund.

Genovés, S. 1963 Estimation of age and mortality. In: Science in Archaeology. D. Brothwell and E. Higgs, eds. Praeger, New York, pp. 342352.

Giles, E., and O. Elliot 1963 Sex determination by discriminant function analysis of crania. Am. J. Phys. Anthrop., $21: 53-68$.

Goldstein, M. S. 1953 Some vital statistics based on skeletal material. Human Biol., 25: 3-12.

Hall, K. R. L. 1965 Behaviour and ecology of the wild Patas monkey, Erythrocebus patas, in Uganda. J. Zoology, 148: 15-87.

Hanna, R. E., and S. L. Washburn 1953 The determination of the sex of skeletons, as illustrated by a study of the Eskimo pelvis. Human Biol., 25: 21-25.

Hansen, S. 1911 Contributions to the anthropology of the East Greenlanders. Meddelelser om Grønland, 39: 151-179.

Holmberg, A. R. 1969 Nomads of the Long Bow: The Siriono of Eastern Bolivia. Natural History Press, New York.

Hooton, E. A. 1930 The Indians of Pecos Pueblo. Yale University Press, New Haven.

Hoyme, L. E., and W. M. Bass 1962 Human skeletal remains from the Tollifero (Ha6) and Clarksville (Mc14) sites, John H. Kerr Reservoir
Basin, Virginia. Bureau of American Ethnology. Bulletin 18 .

Hrdlička, A. 1952 Hrdlička's Practical Anthropometry. T. D. Stewart, ed. Wistar Institute of Anatomy and Biology, Philadelphia.

Ivaniček, F. 1951 Staroslavenska nekropoloa u Ptuju. Slovenska Akademija Znanosti in Umetnosti v Ljubljani, 5.

Johnston, F. E., and C. E. Snow 1961 The reassessment of the age and sex of the Indian Knoll skeletal population: demographic and methodological aspects. Am. J. Phys. Anthrop., $19: 237-244$

Jones, F. L. 1963 A demographic survey of the aboriginal population of the Northern Territory, with special reference to Bathurst Island Mission. Australian Institute of Aboriginal Studies, Occasional Papers, 1.

Keyfitz, N., and W. Flieger 1968 World Population: an Analysis of Vital Data. University of Chicago Press, Chicago.

Kobayashi, K. 1967 Trend in the length of life based on human skeletons from prehistoric to modern times in Japan. J. Faculty of Science (University of Tokyo), III: part 2.

Krogman, W. M. 1962 The Human Skeleton in Forensic Medicine. Charles C Thomas, Springfield.

Kummer, H. 1968 The Social Organization of Hamadryas Baboons: A Field Study. University of Chicago Press, Chicago.

Lebzelter, V. 1934 Einegeborenen kulturen in Südwest- und Südafrika, II. Karl W. Hiersemann, Leipzig.

Lee, R. 1969 !Kung Bushmen subsistence: an input-output analysis. In: Contributions to Anthropology: Ecological Essays. D. Damas, ed. National Museums of Canada, Bulletin 230 pp. $47-65$.

Lewis, T. M., and M. K. Lewis 1961 Eva: an Archaic Site. University of Tennessee Press, Knoxville.

MacCurdy, G. C. 1923 Human skeletal remains from the highlands of Peru. Am. J. Phys. Anthrop., 6: 218-329.

MacDonell, W. R. 1913 On the expectation of life in ancient Rome, and in the provinces of Hispania and Lusitania, and Africa. Biometr., $9: 366-380$.

Meggitt, M. J. 1968 "Marriage Classes" and demography in central Australia. In: Man the Hunter. R. Lee and I. DeVore, eds. Aldine, Chicago.

Mikkelsen, E., and P. P. Sveistrup 1944 The East Greenlanders possibilities of existence, their production and consumption. Meddelelser om Grønland, 134: number 2.

Mukherjee, R., C. R. Rao and J. C. Trevor 1955 The Ancient Inhabitants of Jebel Moya. Cambridge University Press, Cambridge.

Neel, J. V., and N. A. Chagnon 1968 The demography of two tribes of primitive, relatively unacculturated American Indians. Proc. Nat. Acad. Sci., 59:680-689.

Neumann, H. W. 1967 The paleopathology of the Archaic Modoc Rock Shelter inhabitants. Reports of Investigations, Illinois State Museum, 11 . 
Pearson, K. 1902 On the change in expectation of life in man during a period of circa 2000 years. Biometr., I: 261-264.

Pedersen, P. O. 1949 The East Greenland Eskimo dentition. Meddelelser om Grønland, 142 : number 3

Pons, J. 1955 The sexual diagnosis of isolated bones of the skeleton. Human Biol., 27: 12-21.

Rappaport, R. A. 1968 Pigs for the Ancestors: Ritual in th Ecology of a New Guinea People. Yale University Press, New Haven.

Riquet, R. 1953 La population des Grottes de Baye. Bulletin et Mémoires de la Société d'Anthropologie de Paris, 4: 45-67.

Rose, F. G. G. 1960 Classification of kin, age structure and marriage amongst the Groote Eyland t aborigines. Akademie-Verlag, Berlin.

Russell, J. C. 1958 Late Ancient and Medieval Population. Transactions, American Philosophical Society, n.s. 48: number 3.

Salzano, F. M. 1964 Demographic studies on Indians from Santa Catarina, Brazil. Acta Genet. Med. Geme., 13: 278-294.

1971 Demographic and genetic interrelationships among the Cayapo Indians of Brazil. Social Biol,, 18 : 148-160.

Sarkar, S. S. 1960 Clan demography of an Abor village. Proceedings of the National Institute of Sciences in India, 26: 221-232.

Schultz, A. 1961 Some factors influencing the social life of primates in general and of early man in particular. In: Social Life of Early Man. S. L. Washburn, ed. Aldine, Chicago.

Schwidetzky, I. 1958 In welchem Alter starben die Altkanarien? II: Gran Canaria. Homo, 9: $31-33$

Senyürek, M. S. 1951 The longevity of the Chalcolithic and Copper Age inhabitants of Anatolia. Turk Tarih Kurumu, Belleten 15: 447-468.

Sharp, R. L. 1940 An Australian aboriginal population. Human Biol., 12: 481-507.

Skeller, E. 1954 Anthropological and ophthalmological studies on the Angmagssalik Eskimos. Meddelelser om Grønland, 107: number 4.

Smith, G. E., and F. W. Jones 1908 Archaeological survey of Nubia. Bulletin $2: 29-55$.

Smith, T. E. 1960 The Cocos-Keeling Islands: A demographic laboratory. Pop. Studies, 14: 94-130.

Stern, C. 1960 Principles of Human Genetics. Second ed. W. H. Freeman, San Francisco.

Stewart, T. D. 1939 Anthropometric observations on the Eskimos and Indians of Labrador.
Anthropological Series, Field Museum of Natural History, 31 : number 1.

1954 Sex determination of the skeleton by guess and by measurement. Am. J. Phys. Anthrop., 12: 385-392.

Struhsaker, T. T., and S, J. Gartlan 1970 Observations on the behaviour and ecology of the Patas monkey (Erythrocebus patas) in the Waza Reserve, Cameroon. J. Zool, 161: 49-63.

Thieme, F. P., and W. J. Schull 1957 Sex determination from the skeleton. Human Biol., 20: 242-273.

Todd, T. W. 1927 Skeletal records of mortality. Scientific Monthly, 24: 481-496.

Turnbull, C. M. 1965 The Mbuti Pygmies: An ethnographic survey. Anthropological Papers of the American Museum of Natural History, 50: part 3.

Vallee, F. G. 1967 Kabloona and Eskimo in the Central Keewatin. Canadian Research Centre for Anthropology, St. Paul University, Ottawa.

Valloís, H. V. 1937 La durée de la vie chez homme fossile. L'Anthropologie, 47: 499-532.

1960 Vital statistics in prehistoric population as determined from archaeological data. In: Wenner-Gren Symposium: The Application of Quantitative Methods in Archaeology. Quad. rangle, Chicago.

- 1961 The social life of early man: the evidence of skeletons. In: Social Life of Early Man. S. L. Washburn, ed. Aldine, Chicago.

Van den Berghe, H. 1970 Nuclear sexing in a population of Congolese metropolitan newborns. Science, 169: 1318-1320.

Weiss, K. M. 1971 Sex and the single fossil: a comment on the sex ratio of fossil hominid remains. Paper abstracted in: Abstracts, 70th Annual meeting, Am. Anthrop. Assoc.

Wenger, S. 1968 Data to [sic] the anthropology of the Avar period population of the Transdanubia. Anthrop. Hungarica, 8: 59-96.

Wilkinson, R. G. 1971 Prehistoric biological relationships in the Great Lakes region. An. thropological Papers, Museum of Anthropology, University of Michigan, 43.

Williams, B. J. 1965 A model of hunting gathering society and some genetic consequences. Ph. D, thesis, University of Michigan, Ann Arbor.

Yengoyan, A. A. 1971 Demographic factors in the Pitjandjara social organization. In: Australian Aboriginal Anthropology. R. M. Berndt, ed. University of Western Australia Press, Sydney. 